\begin{abstract}
Alessandro Amenta
Instytut Historii, Dziedzictwa Kulturowego, Edukacji i Społeczeństwa, Uniwersytet „Tor Vergata” w Rzymie
\end{abstract}

\title{
O kwestii oryginału, przekładu autorskiego i adaptacji. Wokół polskiej i angielskiej wersji Antygony w Nowym Jorku Janusza Głowackiego
}

\section{Wstęp}

Dwuaktówka Janusza Głowackiego Antygona w Nowym Jorku (dalej: Antygona) została napisana na początku lat 90. w ramach projektu New Voices for a New America (Nowe głosy dla Nowej Ameryki) na zlecenie waszyngtońskiej Arena Stage. Dramaturg przekształcił i uwspółcześnił kilka kluczowych elementów tragedii Sofoklejskiej, dzięki czemu nadał im nowy wymiar i aktualne znaczenie. Antygonę ucieleśnia tu bezdomna i chora psychicznie imigrantka, czyli kobieta potrójnie wykluczona. Jej status pariasa przedstawiony jest jako skutek społecznych dynamik spychających na margines wszystko, co odmienne: „[... ] jak jesteś na ulicy, nikt nie traktuje cię jak człowieka" [Głowacki 2007: 102]. Pozbawionej wszystkiego - rodziny, domu, pracy, godności, ojczyzny, a nawet zdrowego umysłu - bohaterce pozostaje tylko zdolność współodczuwania. To właśnie współczucie wobec drugiej osoby, „le seul amour ici-bas qui soit vrai et juste" [Weil 1949: 220], pobudza ją

1 „Jedyna miłość na świecie, która jest prawdziwa i sprawiedliwa”.Jeśli nie podano inaczej, tłumaczenia fragmentów obcojęzycznych zawartych w niniejszym artykule dokonał jego autor. 
do tego, aby domagać się uznania niezbywalnego prawa człowieka do godnego pochówku.

Akcja rozgrywa się $\mathrm{w}$ ciągu jednej nocy w nowojorskim Tompkins Square Park, a bohaterami jest troje bezdomnych: Portorykanka Anita, rosyjski Żyd Sasza/Sasha ${ }^{2}$ oraz Polak Pchełka/ Flea. Punktem wyjścia fabuły jest śmierć innego kloszarda, Amerykanina Johna/Paulie, którego zwłoki zostają przeniesione na Potter's Field - cmentarz bezimiennych założony na Hart Island. Anita uważa go za swojego kochanka (chociaż to tylko jej fantazja) i chce pochować go w parku, bo, jak mówi, „ja jestem jego rodziną. Tu (pokazuje park) jest jego rodzina” [Głowacki 2007: 59]. Prosi więc Pchełkę i Saszę, aby odzyskali jego szczątki. Po dotarciu na Hart Island mężczyźni zakradają się do kostnicy i zabierają zwłoki, ale po powrocie do parku okazuje się, że wzięli ze sobą trupa nieznajomego. Ku ich zdziwieniu Anita zdaje się tego nie zauważać i z pomocą Saszy chowa nieboszczyka. Kobieta jest tak poruszona uprzejmością Saszy, że natychmiast zaczyna myśleć o wspólnym życiu z nim. Podsłuchawszy ich rozmowę, Pchełka upija Saszę w obawie, że jego towarzysz niedoli go opuści. Wtedy jakiś bezdomny napada na Anitę i ją gwałci. Kobieta desperacko prosi o pomoc, ale zamroczony alkoholem Sasza nie rusza jej na ratunek. Po jakimś czasie Anita wraca i siada w milczeniu na ławce obok Saszy i Pchełki. Sztukę kończy monolog policjanta Jamesa Murphy'ego stanowiący komentarz metanarracyjny i informujący publiczność o tym, co dzieje się poza sceną:

policjant: [... ] Doszly nas idiotyczne plotki, że w parku znajdował się grób jakiegoś bezdomnego. To nieprawda. Przekopaliśmy połowę i nic nie znaleźliśmy. Okazało się, że źródłem tych plotek była chora psychicznie Portorykanka, która przedtem mieszkała w parku. Ta kobieta próbowała kilka razy dostać się z powrotem do parku. Nawet wtedy, kiedy otoczyliśmy go trzymetrowym żelaznym ogrodzeniem. No i w końcu powiesiła się na głównej bramie. Została zabrana na Potter’s Field ... No cóż, pewnym ludziom nie można pomóc. [Głowacki 2007: 111] 


\section{Oryginał i tłumaczenie}

Sztuka została opublikowana po raz pierwszy w języku polskim w czasopiśmie „Dialog” w 1992 roku [Głowacki 1992]. W tym samym numerze ukazał się także szkic Jana Kotta [1992: 155], który określił Antygonę jako jedną z trzech najważniejszych sztuk ostatniego ćwierćwiecza. Po dwóch latach utwór został wznowiony w Stanach Zjednoczonych z kilkoma zmianami w niskonakładowym wydaniu [Głowacki 1994]. Ten sam wariant tekstu najpierw przedrukowano w wyborze utworów dramaturga [Głowacki 1996], a później wydano jako osobną publikację z dołączoną płytą DVD zawierającą nagranie inscenizacji wyreżyserowanej przez Kazimierza Kutza dla Teatru Telewizji [Głowacki 2008]. Trzeci i ostatni wariant tekstu został włączony do zbioru sztuk teatralnych pisarza [Głowacki 2007]³. Wersję anglojęzyczną, przygotowaną przez autora przy współudziale amerykańskiej pisarki i scenarzystki Joan Torres, opublikowano w 1997 roku [Głowacki 1997].

Według terminologii i taksonomii zaproponowanej przez Xosé Manuela Dasilvę [2015] wersja anglojęzyczna wydaje się „przejrzystym przekładem autorskim" (autotraducción transparente), czyli przekładem „en la que figuran informaciones paratextuales que ponen al receptor al tanto de que se halla ante una obra traducida por el autor a partir de un texto escrito en otra lengua"4 [Dasilva 2015: 172]. Niewątpliwie paratekst wydania amerykańskiego wskazuje, że jest to utwór pochodny - na okładce i na stronie tytułowej widnieje napis: „translated by Janusz Głowacki and Joan Torres”. Ponieważ brakuje jakiejkolwiek informacji o tekście wyjściowym, wprowadzony zostaje element „nieprzejrzystości” - nie wiadomo,

3 Nie miejsce tu na szczegółową analizę różnic między tymi wariantami, które polegają na zmianach ortograficznych, składniowych, leksykalnych oraz na usunięciu lub przeformułowaniu niektórych replik i didaskaliów. Zmiany te nie wpływają jednak na rozwój akcji i mają charakter czysto stylistyczny [zob. także Schulze, Weinhagen 2011: 213-214].

4 „[... ] w którym znajdują się informacje paratekstualne objaśniające czytelnikowi, że to utwór przełożony przez autora na podstawie tekstu napisanego w innym języku”.

5 Przekład: Janusz Głowacki i Joan Torres. 
czy to jeden z wariantów, które zostały opublikowane, czy inny tekst, np. jakiś wcześniejszy brulion lub rękopis. Poza tym paratekst wydania amerykańskiego nie wyjaśnia nawet, czy przekład został dokonany z języka polskiego.

Takie dwuznaczności odzwierciedlają prace poświęcone sztuce Głowackiego i poruszające problem powstania utworu. Według niektórych badaczy oryginał to wersja anglojęzyczna, dopiero później przełożona przez autora na język polski [Baniewicz 1993; 2001; Stobierska 2010; Popczyk-Szczęsna 2015]. Inni zaś utrzymują, że oryginał stanowi tekst roboczy napisany w języku angielskim, następnie przerobiony dla amerykańskiego wydania, z którego pochodzi przekład autorski w języku polskim [Nasiłowska 2013]. Pojawiają się też opinie, że sztuka powstała w języku polskim i została później przełożona na angielski [Grossman 2010; 2013; Schultze 2011ab; Schultze, Weinhagen 2011, 2014]. Trzeba zaznaczyć, że w żadnej pracy poświęconej Antygonie nie udało się znaleźć informacji, czy dramaturga, który zmarł w 2017 roku, kiedykolwiek zapytano o to, w jaki sposób i w jakim języku pisał tekst.

Jednym z pierwszych badaczy, którzy zajmowali się Antygona, była Elżbieta Baniewicz, znana teatrolożka, autorka biografii Głowackiego pt. Dżanus. Dramatyczne przypadki Janusza Głowackiego. Baniewicz zakłada, że oryginałem sztuki jest wersja anglojęzyczna, natomiast tekst polski stanowi niezbyt udane tłumaczenie. Przytoczywszy pochlebną opinię Kotta, badaczka stwierdza:

[... ] widocznie [Kott - A.A.] znał oryginalną wersję dramatu, gdzie bohaterowie mówią kalecząc angielszczyznę zgodnie z właściwościami własnych języków. W Ateneum grany jest autorski przekład, który niestety nie zachowuje całego bogactwa kalekiej mowy emigrantów [...]. Literacka gładkość polskiej wersji Antygony ciąży na całym przedstawieniu, można sobie tylko wyobrazić, jakie rezerwy humoru, znaczeń i prawdy można byłoby uruchomić na scenie, dysponując wielojęzyczną wersją sztuki, taką, jaką jest oryginał. [Baniewicz 1993: 117]

Nawet akceptując sprzeczną z informacjami paratekstualnymi tezę, że oryginałem jest wersja anglojęzyczna, warto zauważyć, iż 
wersja ta charakteryzuje się językiem nienacechowanym pod kątem diatopicznym, a w żadnym wypadku nie może być określana jako wielojęzyczna. Nawet jeżeli dzieło nie zostało pierwotnie napisane po angielsku, jak wykażemy w dalszej części artykułu, to z porównania wersji polskiej z angielską wynika, że język niezróżnicowany ze względu na pochodzenie postaci jest zamierzonym wyborem dramaturga, a nie konsekwencją udomawiającego tłumaczenia.

To z kolei opinia Agnieszki Stobierskiej [2010: 229]:

Antigone est la première pièce du dramaturge écrite [par Glowacki - A.A.] en anglais, à la suite d'une commande du théâtre de Washington Arena Stage. Très rapidement Glowacki décide de traduire son texte en polonais. Plus tard, Antigone est traduite en français par Urszula Mikos e Olivier Cohen (1997), puis en plus de vingt langues ${ }^{6}$.

Także ta teza okazuje się sprzeczna z informacjami paratekstualnymi. Poza tym nasuwałoby się pytanie, dlaczego przekład na język francuski miałby być dokonany na podstawie tekstu polskiego, a więc, według rozumowania badaczki, na podstawie tłumaczenia, a nie oryginału7. W każdym razie wątpliwości co do języka, z którego została przełożona sztuka, pozostają. Na przykład w wydaniu francuskim bohaterowie nazywają się tak, jak w wersji amerykańskiej: Paulie, a nie John, Flea, a nie Pchełka, jakby to ostatnie było imieniem własnym, a nie przydomkiem. Nie jest to kwestia drugorzędna, ponieważ w utworach Głowackiego małe, nieprzyjemne owady mają często znaczenie symboliczne i stanowią metaforę wyrzutków i imigrantów ${ }^{8}$.

6 „Antygona jest pierwszą sztuką napisaną [przez Głowackiego - A.A.] po angielsku, na zlecenie teatru Washington Arena Stage. Bardzo szybko Głowacki postanowił przełożyć swój tekst na polski. Później Antygona została przetłumaczona na francuski przez Urszulę Mikos i Oliviera Cohena (1997), a następnie na ponad dwadzieścia języków”.

7 Na stronie tytułowej wydania francuskiego znajduje się informacja: „traduit du polonais".

8 Zob. np. sztukę Polowanie na karaluchy i opowiadanie Polowanie na muchy, na podstawie którego Głowacki napisał scenariusz do filmu Andrzeja Wajdy z 1969 roku o tym samym tytule. Na ten temat pisał Paweł Chmielewski [2002]. 
Inną hipotezę wysuwa Anna Nasiłowska [2013: 144], która określa sztukę Głowackiego jako „utwór pomiędzy językami” i twierdzi, że

okoliczności jego powstania sprawiły, że za wersję pierwotną trzeba uznać wersję angielską, będącą jednocześnie tłumaczeniem. [...] O ile pierwotna wersja angielska dramatu Głowackiego jest tłumaczeniem, to autotłumaczeniami są późniejsze wersje polskie, począwszy od pierwotnie drukowanej w Dialogu, po ostatnią, książkową ze zbioru dramatów 51/2. A oryginału nie ma, tę rolę spełnił jakiś brulion, pisany po angielsku przez pisarza, który nigdy angielskiego nie studiował i nauczył się go z marszu.

Nie wyjaśnia jednak, na czym polegają szczególne okoliczności powstania utworu ani na jakich źródłach opiera przekonanie, że oryginał został napisany po angielsku. Niejasne jest również, dlaczego wersja pierwotna byłaby tłumaczeniem, skoro według badaczki także oryginał został napisany po angielsku.

Podobne informacje podaje również Beata Popczyk-Szczęsna [2015: 151] w niedawno wydanej monografii Powtórzenia i powroty. O dramaturgii Janusza Głowackiego. Twierdzi, że Antygona to utwór

powstał [y] pierwotnie w języku angielskim, przekształcon[y] następnie w wartkie dialogi sceniczne przez amerykańskich native speakerów (we współpracy z autorem, na potrzeby inscenizacji teatralnej), a dopiero potem zapisan [y] w języku polskim, ze znaczną zmianą frazeologii i warunkowanych nią kontekstów semantycznych.

Do nieporozumień przyczynił się fakt, że sztuka powstała na zlecenie amerykańskiego teatru i premiera odbyła się jednocześnie w Polsce i w Stanach Zjednoczonych. Jednak Głowacki nigdy,

9 Odpowiednio 13 lutego 1993 roku w warszawskim Teatrze Ateneum w reżyserii Izabelli Cywińskiej oraz 1 marca 1993 roku w waszyngtońskiej Arena Stage w reżyserii Laurence Maslona. 
ani wcześniej, ani później, nie napisał żadnego utworu w języku angielskim i zawsze korzystał z tłumaczeń native speakerów podczas sporządzania anglojęzycznych wersji swoich utworów. Jak stwierdza Tamara Trojanowska [2003: 272] w interesującym eseju o recepcji i karierze tego polskiego dramaturga w Ameryce, Głowacki „,... ] depends on translators to make his work presentable to theater producers" ${ }^{{ }^{\prime \circ}}$. Opinię tę potwierdza Eva Nagorski, która na początku XXI wieku tłumaczyła razem z Głowackim sztukę pt. Czwarta siostra: „[... ] he knew English well but not well enough to translate his own material”" [z korespondencji prywatnej, 8 października 2017]. Torres dodaje natomiast: „[... ] when I first met him, his English was very bad. It gradually got better but was never easy for him"12 [z korespondencji prywatnej, 11 listopada 2017].

Być może za przekonaniami pewnych badaczy kryje się nieświadome pragnienie kulturalnej rekompensaty, ponieważ istnieją asymetryczne relacje między językiem wyjściowym a językiem docelowym [Grutman 2011: 87]. Przekonanie, że sztuka została przełożona z angielskiego na polski, zakłada istnienie „infraprzekładu autorskiego" (infra-autotraducción) [Grutman 2011: 70-79], czyli przekładu z języka o większym prestiżu symbolicznym na język o mniej prestiżowym statusie. Ta wizja znacząco odbiega od tej, którą oferuje „supraprzekład autorski” (supra-autotraducción) z polskiego na angielski, mający na celu dotarcie do szerszej publiczności, wzrost zauważalności w innym kontekście kulturowym oraz zysk ekonomiczny [Grutman 2011: 86-87]. Innymi słowy, obraz Głowackiego, który pisze w języku angielskim i sam tłumaczy własne utwory, to obraz artysty, który przestał być tylko polskim dramaturgiem, aby stać się międzynarodowym, światowym autorem, a nie artystą zabiegającym o uznanie i popularność zagranicą.

Sytuację zaczyna wyjaśniać Elwira Grossman. Według niej „wbrew rozpowszechnionemu w Polsce przekonaniu, które mylnie podtrzymuje Elżbieta Baniewicz, Głowacki nie napisał tej sztuki

„[... ] polega na tłumaczach w kwestii nadania jego dziełu formy, w jakiej można je zaprezentować producentom teatralnym”.

11 „...] dobrze znał angielski, jednak nie dość dobrze, by tłumaczyć własne teksty”.

$12,[. .$.$] gdy pierwszy raz go spotkałam, jego angielski był bardzo kiepski. Stop-$ niowo polepszał się, ale zawsze sprawiał mu trudność”. 
pierwotnie po angielsku, ale po polsku” [Grossman 2010: 348]. Twierdzenie to doprecyzowuje w późniejszym tekście, w którym pisze:

Głowacki originally wrote Antigone in New York in Polish, but the play premiered in both Poland and the USA in the same year: 1993. The English text was translated (or, I would say, was rewritten/adapted) by the author himself and Joan Torres. [... ] Some interpretations of the play were based on misleading assumptions. A case in point is Elżbieta Baniewicz's reading of the play's language ${ }^{13}$. [Grossman 2013: 244-245]

Jakie relacje łączą różne wersje językowe, ostatecznie wyjaśnia Brigitte Schultze, która sztuce Głowackiego poświęciła kilka wybitnych esejów, a niektóre z nich napisała wraz z Beatą Weinhagen [Schultze 2011ab; Schultze, Weinhagen 2011; 2014] $]^{14}$. Badaczki określają pierwsze wydanie polskie jako Originalfassung („,wersję oryginalną”), Ausgangstext („tekst wyjściowy”), Erstfassung („pierwszą wersję”), a wydanie angielskie jako Bearbeitung („adaptację”). Piszą ponadto o „nieprzezroczystym” powstaniu sztuki i precyzują, że angielski „oryginał”, wspominany przez niektórych badaczy, „scheint nicht zugänglich zu sein. Sie ist zumindest als gedruckte Quelle nicht nachgewiesen"15 [Schultze, Weinhagen 2011: 207]. Analizują także różnice między polskimi wydaniami z lat 1992, 1996 i $2007^{16}$, porównują je z przekładami na język niemiecki, francuski i rosyjski i zauważają, że niektóre z nich mają eklektyczny charakter. Wreszcie stwierdzają, że sztuka jest „ein eher untypisches

13 „Pierwotnie Głowacki napisał Antigone in New York po polsku, niemniej sztuka miała swoją premierę zarówno w Polsce, jak i USA w tym samym, 1993, roku. Tekst w języku angielskim został przetłumaczony (czy też, rzekłabym, napisany od nowa/zaadaptowany) przez samego autora oraz Joan Torres. [...] Niektóre interpretacje tej sztuki oparte zostały na błędnych przypuszczeniach. Można tu przytoczyć przykład odczytania języka sztuki przez Elżbietę Baniewicz”.

14 Pragnę podziękować prof. Brigitte Schultze za udostępnienie mi swoich tekstów o Antygonie.

15 „Raczej nie jest dla nas dostępny, a przynajmniej nigdy nie został opublikowany”.

16 Wprawdzie drugi wariant został opublikowany po raz pierwszy w 1994 roku, a wydanie z 1996 roku to tylko przedruk, tak jak wydanie z 2008 roku. 
Verhältnis von Ausgangstext und Übersetzungen"17, ponieważ wydaje się nie istnieć „ein als kanonisch, verbindlich geltender Ausgangstext" ${ }^{\text {18 }}$ [Schultze, Weinhagen 2014: 13].

Po przedstawieniu zależności między polskim a angielskim tekstem Głowackiego pozostaje jeszcze do rozstrzygnięcia kwestia oryginału. Czy jest nim wersja polska opublikowana w 1992 roku, czy jest też ona tylko późniejszą przeróbką jakiegoś poprzedniego, niezachowanego tekstu? Sam bowiem fakt, że pierwsze wydanie polskie jest utworem oryginalnym, nie oznacza koniecznie, że jest ono oryginałem utworu. Oryginałem mógłby być tekst uprzednio napisany i później zmieniony do druku, co można stwierdzić na podstawie procesu przekładu/adaptacji na język angielski, który nastąpił jeszcze zanim tekst ukazał się w języku polskim.

\section{Wspomagany przekład autorski czy adaptacja?}

Pozornie anglojęzyczna wersja sztuki Głowackiego stanowi przykład „wspomaganego przekładu autorskiego” (aided self-translation [Jung 2002: 24]), czyli przekładu dokonanego przez autora przy współpracy z innym pisarzem lub thumaczem. Jednak liczba i charakter zmian (językowych, stylistycznych, treściowych i strukturalnych), które wprowadzono do utworu, wykraczają poza zakres przekładu, a sam proces współpracy przebiegł inaczej, niż dotychczas zakładano.

Torres, która z Głowackim przygotowała angielską wersję sztuki, stanowczo zaprzecza istnieniu angielskiego oryginału i tak ilustruje przebieg współpracy z polskim dramaturgiem:

Janusz never prepared an English draft. He always wrote in Polish. He'd come to me with parts of his draft written in Polish and then tell me what he'd written. He continued writing the play in Polish at my place and every day after he'd written he'd tell me what he'd done, and we'd discuss it ${ }^{19}$. [z korespondencji prywatnej, 25 września 2017] 
Oryginał stanowi więc tekst w języku polskim, który Głowacki zaczął pisać przed spotkaniem z Torres i który pisał dalej podczas pobytu u amerykańskiej scenarzystki: „When Janusz came to LA with the play much of it had only been sketched out by him in Polish"20 [z korespondencji prywatnej, 25 listopada 2017]. Głowacki pracował jednocześnie nad polską i angielską wersją utworu razem z Torres: „[... ] he would stay with me at my place in Santa Monica and we would work together on both translating into English and altering elements of the Polish draft" ${ }^{21}$ [z korespondencji prywatnej, 25 września 2017]. Upływ czasu między pisaniem oryginału a przekładem jest nieznaczny, gdyż to, co dramaturg pisał, sprawdzano, dyskutowano i tłumaczono (albo raczej przerabiano i adaptowano) wspólnie z Torres w dniu następnym. Mamy więc do czynienia $\mathrm{z}$,symultanicznym przekładem autorskim” (simultaneous self-translation), czyli przekładem „executed while the first version is still in process"22 [Grutman 2009: 20]. Jednak praca nie polegała tylko na tłumaczeniu sztuki, ponieważ dramaturg nieustannie poprawiał, zmieniał, przekształcał także polski tekst. Rękopis w języku polskim używany do sporządzenia angielskiej wersji nie zachował się $(„[. .$.$] it was all handwritten and the pages got discarded once$ we'd worked on them in English" ${ }^{23}$ [z korespondencji prywatnej, 25 września 2017]), ale najprawdopodobniej stanowił podstawę polskiej wersji opublikowanej w 1992 roku.

Torres udostępniła nam notatki, schemat z 4 czerwca 1992 roku (zob. ryc. 1-2) oraz trzy wersje robocze w języku angielskim (zob. ryc. 3-4) pokazujące gruntowne przeredagowanie, któremu została poddana sztuka ${ }^{24}$. Polski tekst opublikowany w „Dialogu”

nie opowiadał mi, co napisał. Pisanie sztuki kontynuował w języku polskim u mnie, codziennie mówił mi, co napisał dnia poprzedniego, i dyskutowaliśmy o tym”.

„Gdy Janusz przyjechał do Los Angleles ze swoją sztuką, była ona w większości zaledwie szkicem, jaki napisał po polsku”. „[... ] zostawał ze mną u mnie w Santa Monica i razem pracowaliśmy zarówno nad przekładem na angielski, jak i nad zmianą elementów polskiego projektu”. „[... ] sporządzanym jeszcze podczas tworzenia pierwszej wersji”.

$23,[\ldots]$ cały napisany został ręcznie, a jego strony były wyrzucane, gdy przerobiliśmy je po angielsku".

Wersje robocze $\mathrm{w}$ języku angielskim zachowane są w prywatnym archiwum Torres. Tu odznaczamy je skrótami: EN 1, EN 2, EN 3. Tylko na pierwszej wersji figuruje data (4 czerwca 1992 roku). 
nie jest więc oryginałem, ale późniejszą wersją, noszącą ślady współpracy z Torres na poziomie językowym, stylistycznym i tematycznym. To jej zawdzięczamy zmianę narodowości bohaterki, która pierwotnie była kobietą z Europy Wschodniej, a nie Portorykanką, oraz odmienną charakteryzację postaci - modyfikacje, które potem sam Głowacki wprowadził do tekstu polskiego:

When he first brought what he had written to me, the three main characters were all Eastern European. The woman was insane from the beginning. I said: crazy characters get old very quickly and if he didn't want the audience to tune out on her, she needed to be more rational. So, altering her character was a big change. I also suggested that woman be Puerto Rican and that changed the tone quite a bit. [...] I felt she was not sympathetic, so we worked a lot on her ${ }^{25}$. [z korespondencji prywatnej, 25 września 2017]

Torres sprawdziła, jak przebiegają portorykańskie ceremonie żałobne, których wprowadzenie do tekstu nadało specyficzną, etniczno-kulturową konotację postaci Anity i zanurzyło scenę pochówku w magiczno-rytualnej aurze. Posłużyło także podkreślaniu wizerunku kobiety jako „wybranki Boga”, która pragnie godnie pochować innego bezdomnego nie tylko z powodu litościwego impulsu, lecz także by wykonać zadanie powierzone jej przez Stwórcę (zob. I, 7). Inna podstawowa zmiana dotyczy monologów policjanta, które w języku angielskim zostały gruntownie skrócone i przerobione przy pomocy odmiennego, bardziej potocznego rejestru językowego. Właśnie podczas pracy nad postacią policjanta wyszły na jaw odmienne wizje Głowackiego i Torres:

We had the most heated discussions about the policeman. [... $]$ His [Głowacki's - A.A.] draft had the policeman sounding

25 „Gdy po raz pierwszy przyniósł mi swoje zapiski, wszystkie trzy główne postacie pochodziły z Europy Wschodniej. Kobieta już od początku była obłąkana. Powiedziałam, że niepoczytalne postaci bardzo szybko się starzeją i jeśli nie chce, by widzowie ją zignorowali, musiałaby być bardziej racjonalna. Tak więc modyfikacja jej postaci była wielką zmianą. Zasugerowałam również, by kobieta była Portorykanką, co w znacznym stopniu zmieniło wydźwięk. [...] W moim odczuciu nie była współczująca, więc poświęciliśmy jej wiele pracy”. 
very much like a European authority figure, his wit very black Polish humor. I kept writing and rewriting that part. It played pretty well on stage, but there were still bits Janusz wanted to hang on to that made the character feel somewhat inconsistent. [...] I rewrote his policeman's speeches but there were some things Janusz thought were funny and wouldn't budge on, even though they made the character sound inconsistent ${ }^{26}$. [z korespondencji prywatnej, 25 września 2017]

Można założyć, że również wersja polska nosi jakieś ślady skrócenia monologów policjanta. W wersji angielskiej zostały z nich usunięte, streszczone lub przeformułowane liczne fragmenty.

Osobną kwestią są imiona dramatis personae. Pierwotnie główna bohaterka miała na imię Jola/Yola, ale za namową Torres zmieniono je na Annie [EN 1], następnie na Anę [EN 2], a w końcu na Anitę [EN 3; Głowacki 1997 $]^{27}$. Według Torres

Yola became Anita when she switched from being a European to being a Puerto Rican. I felt there were too many Eastern Europeans and there needed to be someone representing another immigrant population. Janusz agreed ${ }^{28}$. [z korespondencji prywatnej, 2 października 2017]

Jednak imię Jola nie zniknęło ze sztuki, gdyż nadano je kobiecie Pchełki, która w wersjach roboczych [EN 1, EN 2, EN 3] miała na

„Najgorliwsze dyskusje prowadziliśmy na temat policjanta. [... ] W jego [Głowackiego - A.A.] projekcie policjant sprawiał wrażenie europejskiego autorytetu o bardzo czarnym, polskim poczuciu humoru. Tę rolę przepisywałam na okrągło. Całkiem nieźle wyszła na scenie, ale wciąż pozostawały pewne elementy, na które Janusz się uparl, a za sprawą których postać ta wydawała się nieco niespójna. [...] Napisałam na nowo kwestie policjanta, jednak pewne rzeczy Janusz uważał za zabawne i nie chcial ustąpić w ich przypadku nawet pomimo tego, że przez nie postać sprawiała wrażenie niespójnej”.

Z korespondencji prywatnej, 2 października 2017. Zob. także schemat dołączony do niniejszego artykułu. W notatkach Torres pojawia się lista imion, które były brane pod uwagę, m.in. Angelina, Anabel, Anastasia, Ana Maria.

28 „Yola została Anitą, gdy zamiast Europejską stała się Portorykanką. Miałam odczucie, że postaci z Europy Wschodniej było za dużo i brakowało kogoś, kto reprezentowałby inną populację imigrantów. Janusz na to przystał”. 
imię Ada. We wszystkich wersjach roboczych w języku angielskim rosyjski Żyd nosił imię Boris, które później zostało zmienione na Sasha/Sasza. Torres wyjaśnia, że ta decyzja została podjęta, bo „Boris seemed too generic Russian”29 [z korespondencji prywatnej, 2 października 2017]. Jedyna nazwa, która pozostała na wszystkich etapach pracy nad tekstem w wersji pierwotnej, to przydomek Pchełka/Flea. Policjant nazywa się Jim Murphy we wszystkich wersjach w języku angielskim i w pierwszym wydaniu polskim, ale od drugiego wydania stał się Jamesem Murphym. Najwyraźniejsza modyfikacja dotyczy jednak postaci zmarłego, który w tekście angielskim nosi imię Paulie, a w polskim John. Torres nie pamięta, aby Głowacki kiedykolwiek mówił jej o imieniu John, ani nie kojarzy, czy to imię było obecne w polskim oryginale [z korespondencji prywatnej, 25 września 2017]. Można więc założyć, że dramaturg wprowadził je w późniejszej fazie pracy nad tekstem i że w tej formie pojawia się ono w pierwszym wydaniu polskim. Jednak począwszy od drugiego wydania, choć $\mathrm{w}$ spisie dramatis personae pozostał John, w dialogach używa się często zdrobnienia Johnny. Wynika to być może z wplywu tekstu angielskiego, w którym postać zmarłego nosi imię wywołujące uczucia bliskości, poufałości i kameralności ${ }^{30}$. Możliwe, że w tekście roboczym napisanym w języku polskim Głowacki nie wybrał jeszcze imienia dla tej postaci, a podczas przygotowywania tekstu do druku zdecydował się na imię John z powodu jego stereotypowej funkcji - bohatera o typowym imieniu anglosaskim publiczność mogła uznać za Amerykanina par excellence.

Zasadniczo zmieniona została też struktura dramatu. Dwie pierwsze wersje robocze w języku angielskim zawierają czternaście scen, trzecia - piętnaście, wersja drukowana - czternaście, a wszystkie wydania polskie - szesnaście. Różnice wynikają najczęściej z cięć, przesunięć, złączeń i dotyczą zarówno poszczególnych replik, jak i całych dialogów, które zostały usunięte, streszczone

Schultze [2011b: 331-332] sugeruje, że imię Paulie stanowi aluzję do Polinika, brata Antygony w tragedii Sofoklesa, który w tekście Głowackiego ogrywa podobną rolę. 
lub przeniesione do innych miejsc utworu. Celem tego zabiegu było zapewne nie tylko szlifowanie tekstu pod kątem formalnym i stylistycznym poprzez nadanie mu szybszego tempa, większej zwięzłości i potoczniejszego rejestru językowego, lecz także zmiana dynamik narracyjnych. Na przykład w pierwszej wersji roboczej w języku angielskim Anita nie zostaje zgwałcona. Gwałt został dodany dopiero $w$ trzeciej wersji. Można więc przypuszczać, że scena ta nie była obecna w polskim oryginale. Pierwszą wersję roboczą $\mathrm{w}$ języku angielskim kończą trzy krótkie monologi bohaterów [EN 1 (akt II): 13], które zostają przerwane przez wtargnięcie policji do parku, po czym następuje monolog policjanta [EN 1 (akt II): 14]. W każdej wersji językowej monolog ten pozostał prawie niezmieniony, zaś monologi trzech innych postaci umieszczono w różnych punktach tekstu. Didaskalia dostarczające informacji o czasie, miejscu akcji oraz mimice bohaterów zostały prawie w całości napisane na nowo. Zmiany dotyczyły też elementów kulturowych, odniesień historycznych, imion postaci publicznych, marek alkoholi, wydarzeń bieżących, które w większości poddano procedurom substytucji, usunięcia, uogólnienia, redukcji.

Zarówno we wszystkich wydaniach polskich, jak i w pierwszej wersji roboczej w języku angielskim akcja rozgrywa się w nowojorskim Tompkins Square Park. Natomiast w kolejnych wersjach [EN 2; EN 3; Głowacki 1997] mowa jest tylko o „typical New York park” ${ }^{11}$. W pierwszym wydaniu polskim autor wspomina o demonstracji przeciwko wojnie w Zatoce Perskiej [Głowacki 1992: 5], która służy mu do umieszczenia akcji w konkretnym kontekście czasowym; tak samo jest we wszystkich wersjach roboczych w języku angielskim. Jednak począwszy od drugiego wydania polskiego mowa jest tylko o niesprecyzowanym proteście przeciwko polityce rządu [Głowacki 1994: 5], a w wydaniu amerykańskim odniesienie to zostało wręcz usunięte. We wszystkich wydaniach polskich wspomina się o winie Pershing i wódce Stolicznaja, które jednak $\mathrm{w}$ ostatniej wersji roboczej w języku angielskim [EN 3] zostały zastąpione ogólnymi nazwami: wine i vodka. W wydaniu amerykańskim zamiast Pershingu pojawia się natomiast ekwiwalent 
funkcjonalny: tanie wino kalifornijskie Nightrain ${ }^{32}$. W pierwszym wydaniu polskim autor osiąga efekt komiczny dzięki zaliczeniu do grona znanych intelektualistów także generała Schwarzkopfta [Głowacki 1992: 34], podobnie w wydaniu amerykańskim, gdzie jednak wspomniany jest generał Colin Powell [Głowacki 1997: 68]. W późniejszych wydaniach polskich efekt komiczny został wyeliminowany i wspomina się o prawdziwym intelektualiście - pisarzu Philipie Rocie [Głowacki 2007: 97]. Inny przykład konwersji to określenie zmarłego mianem „arystokraty z Bostonu” we wszystkich wydaniach polskich, podczas gdy w języku angielskim, począwszy od trzeciej wersji roboczej, Paulie opisywany jest jako WASP [White Anglo-Saxon Protestant]. Wreszcie obserwuje się redukcję tekstu w scenie, w której Anita zwierza się Saszy, że kiedyś marzyła o otwarciu bodegi w Portoryko. W tekście polskim autor ucieka się do rozwlekłego opisu: „[...] taki mały sklep ze wszystkim... Kawa, owoce, sery, soki, może i hamburgery” [Głowacki 1992: 31], podczas gdy w języku angielskim mowa jest tylko o „little grocery store” („sklepiku spożywczym”) - już od pierwszej wersji roboczej. Przy tłumaczeniu elementów kulturowych nie została zastosowana spójna strategia, choć w języku angielskim obserwuje się pewną tendencję do uogólnienia, redukcji lub usunięcia terminów zbyt naznaczonych.

Nie zawsze jednak Głowacki przyjmował sugestie Torres, tak jak stało się to w przypadku zmiany tytułu: „We had a lot of discussion about the title. I thought it should have been Antigone in the Park because it was more generic. He thought the critics would like it better if it was New York" ${ }^{33}$ [z korespondencji prywatnej, 25 września 2017]. Być może autor chcial podkreślić odniesienia do Sofoklesa także poprzez stylizację tytułu (zob. np.Edyp w Kolonie), zawierając w nim współczesny klucz interpretacyjny, z Nowym Jorkiem jako wyraźnym symbolem Zachodu. Thunderbird, Cinco, Wild Irish Rose i właśnie Nightrain.

33 „Odbyliśmy wiele dyskusji na temat tytułu. Według mnie miał on brzmieć Antigone in the Park (Antygona w parku), ponieważ był on bardziej ogólny. Jego zdaniem krytycy preferowali jednak Nowy Jork”. 


\section{Wnioski}

Opisując strategie przekładu autorskiego najczęściej używane przez polskich pisarzy, Andrea Ceccherelli [2013: 169-170] podkreśla, że zjawisko to „è strettamente connesso alla storia politica del paese”, i dodaje: „[... espropriazione, esperimento, esilio: queste le tre parole chiave, i tre contesti sul cui sfondo si sviluppa la storia dell'autotraduzione nel Novecento polacco" ${ }^{35}$. Według tego klucza Głowacki należy do pisarzy, którzy stosowali przekład autorski wskutek emigracji politycznej. Kiedy w Polsce został ogłoszony stan wojenny, dramaturg przebywał w Londynie z okazji premiery swojej sztuki w Royal Court Theatre. Postanowił wtedy nie wracać do kraju i wkrótce wyemigrował do Stanów Zjednoczonych [Głowacki 2004: 5-19]. Jego przekłady autorskie mają charakter epizodyczny i pochodzą z okresu, gdy pisarz miał już międzynarodową renomę, jego sztuki były wystawiane w amerykańskich teatrach i publikowane przez prestiżowe wydawnictwa. Nie służyły mu do autopromocji na amerykańskiej scenie teatralnej, ale odpowiadały pragnieniu większej kontroli nad rezultatem pracy tłumaczy z powodu niezadowolenia z poprzednich przekładów swoich dzieł. Zostało to potwierdzone przez Torres: „[... ] he hadn't been satisfied with his previous English translators, especially on Fortinbras Gets Drunk, which changed drastically once we got to work on it" ${ }^{36}$ [z korespondencji prywatnej, 20 listopada 2017].

Torres nie zna polskiego i nie jest zawodową tłumaczką, lecz pisarką i scenarzystką ${ }^{37}$. Tak przedstawia pracę nad anglojęzyczną wersją Antygony: „[... ] the way we worked was: he would write in na których tle rozwija się historia przekładu autorskiego w polskim xx wieku”.

$36, \ldots[\ldots]$ nie był on zadowolony ze swoich poprzednich tłumaczy języka angielskiego, zwłaszcza w przypadku sztuki Fortynbras się upit, która radykalnie się zmieniła, gdy zaczęliśmy nad nią pracować”.

37 „Let me say first off that Janusz wrote in Polish and I do not speak Polish” („W pierwszej kolejności powiem, że Janusz pisał po polsku, a ja po polsku nie mówię") [z korespondencji prywatnej, 25 września 2017]. Torres napisała scenariusz do kultowego filmu horror Blacula (1972) i do jego sequela Scream Blacula Scream (1972), sztukę Better Half Dead: A Comedy Thriller (1998) oraz książkę 
Polish and then tell me in English what he was trying to achieve. We'd discuss it and try different possibilities" ${ }^{38}[$ z korespondencji prywatnej, 25 września 2017]. Do adaptacji niezbędny stał się etap pośredni - ustne przeformułowanie tekstu wyjściowego w języku angielskim ze strony autora. Trzeba jednak zaznaczyć, że owo przeformułowanie odbywało się podczas procesu pisania tekstu wyjściowego w języku polskim, a nie po jego zakończeniu: po napisaniu danego fragmentu Głowacki tłumaczył go ustnie na angielski, po czym wraz z Torres dokonywali roboczego przekładu pisemnego, który często poddawany był gruntownej przeróbce. Zabieg ten zachował charakter symultaniczny, o którym była mowa w odniesieniu do Grutmana.

Głowacki wykorzystał podobną metodę także w przypadku Czwartej siostry, którą tłumaczył na angielski wraz z amerykańską scenarzystką Nagorski. Wtedy ustne przeformułowywanie nie było potrzebne, ponieważ współpracowniczka znała język wyjściowy. Ich praca przebiegła w następujący sposób: Głowacki czytał na głos tekst po polsku, Nagorski tłumaczyła ze słuchu, po czym razem sprawdzali i zmieniali przekład. Oto jak scenarzystka opisuje proces współtłumaczenia:

He first wrote The Fourth Sister in Polish, and we then translated it together into English. He would read his handwritten text aloud in Polish and I would type it in English on the computer, producing an instant translation. Sometimes, I'd get his pages and work on them on my own. He then would read the translations over, making suggestions. He had a remarkable ear for what rang true and, more importantly, what didn't. Every single word was meaningful to him, and dialogue was his specialty ${ }^{39}$. [z korespondencji prywatnej, 8 października 2017]

Men Who Hate Women and the Women Who Love Them: When Loving Hurts and You Don't Know Why (2002, wraz z Susan Forward).

„[... ] pracowaliśmy w następujący sposób: on pisał po polsku, a potem po angielsku opowiadał mi, co chciał osiągnąć. Omawialiśmy to, wypróbowując różne możliwości". 
Również w przypadku Czwartej siostry, choć w mniejszym stopniu, praca nad przekładem wpłynęła na tekst polski, do którego zostało wprowadzonych kilka zmian: „Yet once in a while, we'd come up with something so good in English, he'd then change the wording in the Polish version to make it closer to the new English

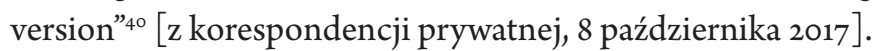

Współpracę między Głowackim i Torres należy ujmować raczej w kategoriach wspólnej adaptacji, a nie wspomaganego przekładu, choć tak przedstawia się w paratekście wydania amerykańskiego ${ }^{41}$. $\mathrm{Na}$ ten rodzaj partnerskiego współdziałania wskazują: metoda pracy nad angielską wersją sztuki, liczba zmian wprowadzonych w tekście (częściowo zaproponowanych przez współpracowniczkę polskiego dramaturga), dostosowanie utworu do innego kontekstu kulturalnego oraz chęć zaspokojenia potrzeb nowej publiczności. Jednocześnie także polska wersja Antygony nosi ślady tej współpracy i widoczny jest wpływ wersji angielskiej na jej ostateczny

go po angielsku na komputerze, tworząc natychmiastowy przekład. Niekiedy dostawałam jego strony i samodzielnie nad nimi pracowałam. Następnie czytał jeszcze raz tłumaczenia, sugerując zmiany. Cechowała go niesłychana łatwość oceny, co brzmi wiarygodnie, a przede wszystkim - co tak nie brzmi. Każde jedno słowo było dla niego istotne, a jego specjalnością były dialogi”.

„Niemniej jednak raz na jakiś czas wymyślaliśmy coś, co brzmiało genialnie po angielsku; zmieniał wtedy sformułowanie w polskiej wersji, aby było bliższe tej nowej, anglojęzycznej”.

41 Na nowo powstałej stronie internetowej pisarki można przeczytać, że Antigone in New York i Fortinbras Gets Drunk byly „translated/adapted by Joan Torres” („przetłumaczone/zaadaptowane przez Joan Torres”), co możemy uważać za swojego rodzaju sprostowanie informacji znajdujących się w paratekście wydania amerykańskiego [zob. Antigone in New York 2020]. To, że w anglojęzycznym wydaniu Fortinbrasa ... nie ma informacji o wkładzie Torres, ona sama wyjaśnia w następujący sposób: „Because he had previously committed to other translators I didn't get any credit on it. [...] That was the first project we worked on together. And because I am a writer as well we did a lot of restructuring, we added characters and the whole process took over a year. We worked well together and that is why he kept coming back with his future projects” („Ponieważ wcześniej zobowiązał się do współpracy z innymi tłumaczami, nie otrzymałam z tego względu żadnego uznania. [...] To był pierwszy projekt, nad jakim wspólnie pracowaliśmy. A ponieważ jestem także pisarką, przeprowadzaliśmy sporo restrukturyzacji, dodawaliśmy postaci, a cały proces trwał ponad rok. Dobrze nam się razem pracowało i dlatego wielokrotnie wracał z następnymi projektami”) [z korespondencji prywatnej, 10 listopada 2017]. 
kształt. Symultaniczna praca nad dwiema wersjami językowymi oraz ich wzajemne oddziaływanie wydają się zatem zaprzeczać tezie o linearności procesu „ttumaczenia/adaptacji” w stosunku do „oryginału” oraz o istniejącej między nimi hierarchii.

\section{Skróty}

EN 1 - pierwsza anglojęzyczna wersja robocza sztuki Antigone in New

York (oryginał zachowany w prywatnym archiwum Joan Torres)

EN 2 - druga anglojęzyczna wersja robocza sztuki Antigone in New York

(oryginał zachowany w prywatnym archiwum Joan Torres)

EN 3 - trzecia anglojęzyczna wersja robocza sztuki Antigone in New York

(oryginal zachowany w prywatnym archiwum Joan Torres)

\section{Bibliografia}

Antigone in New York (2020), [dostęp: 6 marca 2020], https://www.joantorres.com/adaptations.

Baniewicz Elżbieta (1993), Antygona wśród gwiazd, „Twórczość”, nr 5, s. 113-117.

Baniewicz Elżbieta (2001), Janusz Głowacki, „Antygona w Nowym Jorku”. Antygona w Tompkins Park, w: Dramat polski. Interpretacje. Część 2: Po roku 1918, red. Jan Ciechowicz, Zbigniew Majchrowski, słowo/ obraz terytoria, Gdańsk, s. 355-363.

Ceccherelli Andrea (2013), Autotraduttori polacchi del Novecento: un saggio di ricognizione, w: Autotraduzione e riscrittura, red. Andrea Ceccherelli, Gabriella Elina Imposti, Monica Perotto, Bononia University Press, Bologna, s. 169-182.

Chmielewski Paweł (2002), Muchy, karaluchy, pchly. Emigranci i emigracja wewnętrzna. „Kopciuch”, „Polowanie na karaluchy”, „Antygona w Nowy Jorku” Janusza Gtowackiego, w: tegoż, Stowacki w supermarkecie. Szkice o polskim dramacie, Czarny kot, Gdańsk, s. 47-70.

Dasilva Xosé Manuel (2015), La opacidad de la autotraducción entre lenguas asimétricas, „Trans. Revista de Traductologia”, nr 19/2, S. 171-182, [dostęp: 25 listopada 2020], https://tinyurl.com/ y4muqm2q.

Głowacki Janusz (1992), Antygona w Nowym Jorku, „Dialog”, nr 10, s. 5-40.

Głowacki Janusz (1994), Antygona w Nowym Jorku, Bicentennial Publishing Company, New York. 
Głowacki Janusz (1996), Antygona w Nowym Jorku, w: tegoż, Ścieki, skrzeki, karaluchy. Utwory prawie wszystkie, Polska Oficyna Wydawnicza BGW, Warszawa, s. 13-83.

Głowacki Janusz (1997), Antigone in New York, przeł. Janusz Głowacki, Joan Torres, Samuel French, New York-Hollywood-LondonToronto.

Głowacki Janusz (2004), Z głowy, Świat Książki, Warszawa.

Głowacki Janusz (2007), Antygona w Nowym Jorku, w: tegoż, $5^{1 / 2}$. Dramaty, Świat Książki, Warszawa, s. 30-111.

Głowacki Janusz (2008), Antygona w Nowym Jorku, Elipsa, Warszawa. Grossman Elwira (2010), O plynnej polskości, diasporycznych horyzontach $i$ komparatystyce w Glasgow uwag kilka, w: Literatura polska w świecie, t. 3: Obecności, red. Romuald Cudak, Uniwersytet Śląski, Gnome, Katowice, s. 345-357.

Grossman Elwira (2013), Transnational or Bi-cultural? Challenges in Reading post-1989 Drama 'Written outside the Nation', w: Polish Literature in Transformation, red. Ursula Phillips, LIT Verlag, Münster, s. 241-250.

Grutman Reiner (2009), Self-Translation, w: Routledge Encyclopedia of Translation Studies, red. Mona Baker, Gabriela Saldanha, Routledge, London, s. 257-260.

Grutman Reiner (2011), Diglosia y autotraducción vertical (en y fuera de España), w: Aproximaciones a la autotraducción, red. Xosé Manuel Dasilva, Helena Tanqueiro, Academia del Hispanismo, Vigo, s. 69-91. Jung Verena (2002), English-German Self-translation of Academic Texts and its Relevance for Translation Theory and Practice, Peter Lang, Frankfurt.

Kott Jan (1992), Antygona powiesiła się w Tompkins Square Park, „Dialog”, nr 10, s. 153-155.

Nasiłowska Anna (2013), Głowacki - dwujęzycznie (na przykładzie „Antygony w Nowym Jorku”), w: Dramaturgia Janusza Gtowackiego trochę teatru, red. Jan Ciechowicz, Wydawnictwo UG, Gdańsk, s. 144-154.

Popczyk-Szczęsna Beata (2015), Powtórzenia i powroty. O dramaturgii Janusza Głowackiego, Wydawnictwo Uś, Katowice.

Schultze Brigitte (2011a), "Antygona w Nowym Jorku” Janusza Głowackiego po polsku, angielsku i niemiecku, czyli: o jakiej sztuce scenicznej mówimy?, „Oder Übersetzen”, nr 2, s. 130-143.

Schultze Brigitte (2011b), Bedeutungsbildung zwischen textuellem Angebot und individuellem Rezeptionshorizont: Janusz Głowackis „Antygona w Nowym Jorku” („Antigone in New York”) - polnisch, englisch und 
deutsch, „Convivium. Germanistisches Jahrbuch Polen”, s. 321-343, [dostęp: 26 listopada 2020], https://tinyurl.com/y6atb732.

Schultze Brigitte, Weinhagen Beata (2011), Janusz Głowackis „Antigone in New York" international: Selektion, Substitution und Exponierung von Sinnangebot, „Forum Modernes Theater”, vol. 26, nr 1-2, s. 207-222, [dostęp: 26 listopada 2020], https://muse.jhu.edu/article/554845. Schultze Brigitte, Weinhagen Beata (2014), Theaterlandschaften als Bedingungsrahmen für literarischen, intermedialen und kulturellen Transfer: Janusz Głowackis Dramen „Kopciuch” („Aschenkinder”) und "Antygona w Nowym Jorku” („Antigone in New York”), „Rocznik Komparatystyczny", nr 5, s. 11-47.

Stobierska Agnieszka (2010), Antigone des 'homeless' dans la 'comédie du désespoir' de Janusz Glowacki: „Antigone à New York”, w: Les Antigones contemporaines (de 1945 à nos jours), red. Rose Duroux, Stéphanie Urdician, Presses Universitaires Blaise Pascal, Clermont-Ferrand, s. 229-241.

Trojanowska Tamara (2003), Many Happy Returns: Janusz Glowacki and His Exile Experience, w: Living in Translation: Polish Writers in America, red. Halina Stephan, Rodopi, Amsterdam-New York, s. 259-288.

Weil Simone (1949), L'Enracinement. Prélude à une déclaration des devoirs envers l'être humain, Gallimard, Paris.

Alessandro Amenta

On the original, the self-translation and the adaptation. Considerations about the Polish and the English Version of Janusz Głowacki's Antigone in New York

Janusz Głowacki's internationally acclaimed tragicomedy inspired by Sophocles' Antigone has been the subject of intense debate and misinterpretations. The article aims to demonstrate that the play was primarily written in Polish, and that the English version is an adaptation/rewriting made by the author in collaboration with the American screenwriter Joan Torres. Furthermore, it shows that the English version was created while the writing of the Polish text was still in progress, so that the former influenced and left clear traces in the latter, questioning the traditional hierarchy between the original and the translated or adapted text.

Keywords: self-translation; adaptation; Janusz Głowacki; Antigone in New York. 
Alessandro Amenta - doktor habilitowany, wykłada na Uniwersytecie „Tor Vergata” w Rzymie. Zajmuje się translatoryką, onomastyką, xx-wieczną literaturą polską, studiami genderowymi w Europie Wschodniej. Autor monografii: Il discorso dell'Altro. La costruzione delle identità omosessuali nella narrativa polacca del Novecento (2008) i Le parole e il silenzio. La poesia di Zuzanna Ginczanka e Krystyna Krahelska (2016). Przełożył na język włoski utwory Witolda Gombrowicza, Adama Zagajewskiego, Wiesława Myśliwskiego, Zuzanny Ginczanki, Andrzeja Stasiuka, Eugeniusza Tkaczyszyna-Dyckiego, Izabeli Filipiak, Piotra Pazińskiego, Łukasza Jarosza i innych. Redaktor naczelny czasopisma „pl.it / rassegna italiana di argomenti polacchi” (plitonline.it). Współzałożyciel Włoskiego Stowarzyszenia Polonistów. W 2012 roku został uhonorowany przez Ministerstwo Kultury i Dziedzictwa Narodowego odznaką „Zasłużony dla Kultury Polskiej”. 


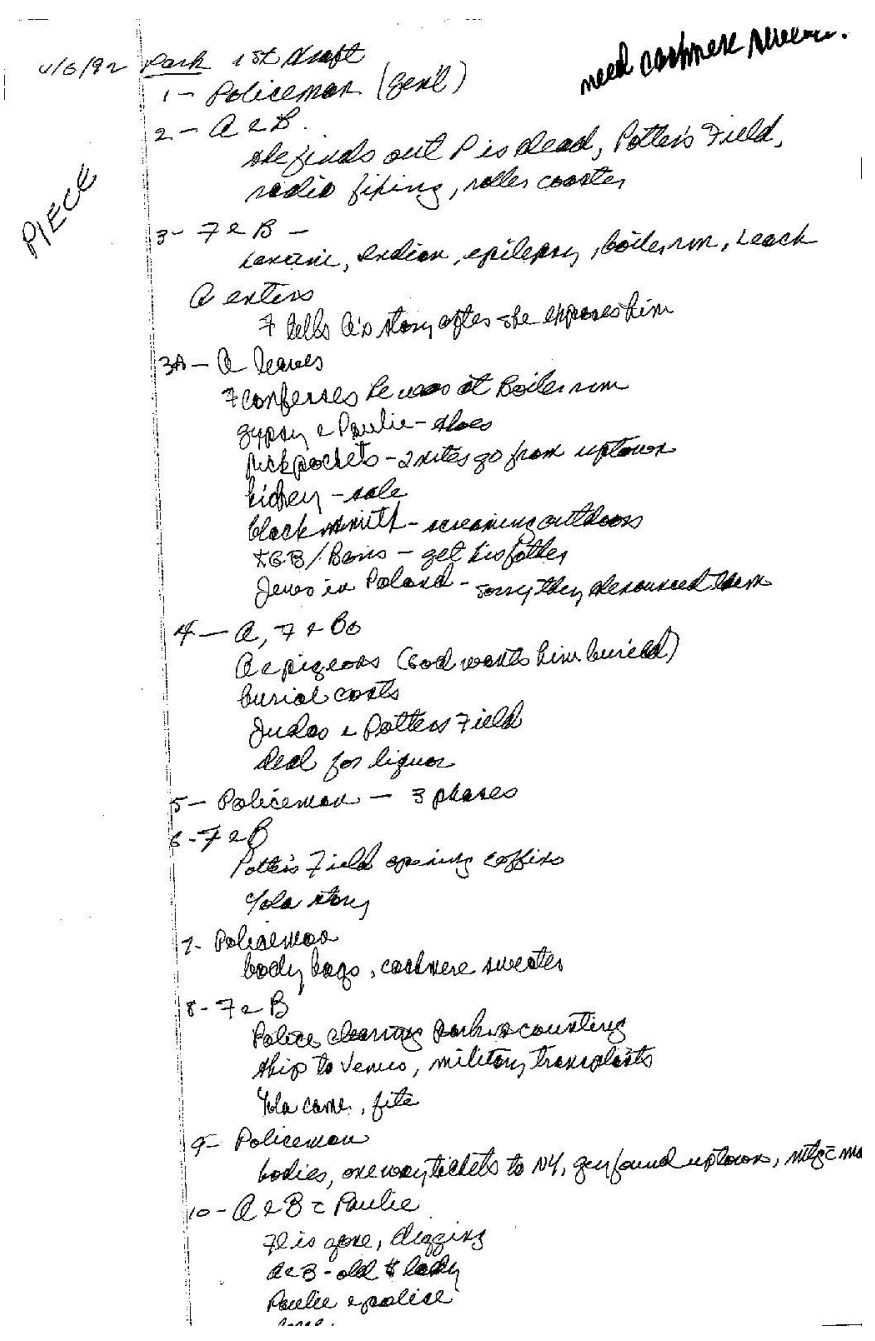

Ryc. 1-2 Schemat EN 1. Dokument datowany na 4 czerwca 1992. A - Annie, B - Boris, F - Flea, P - Paulie. Dzięki uprzejmości Joan Torres 


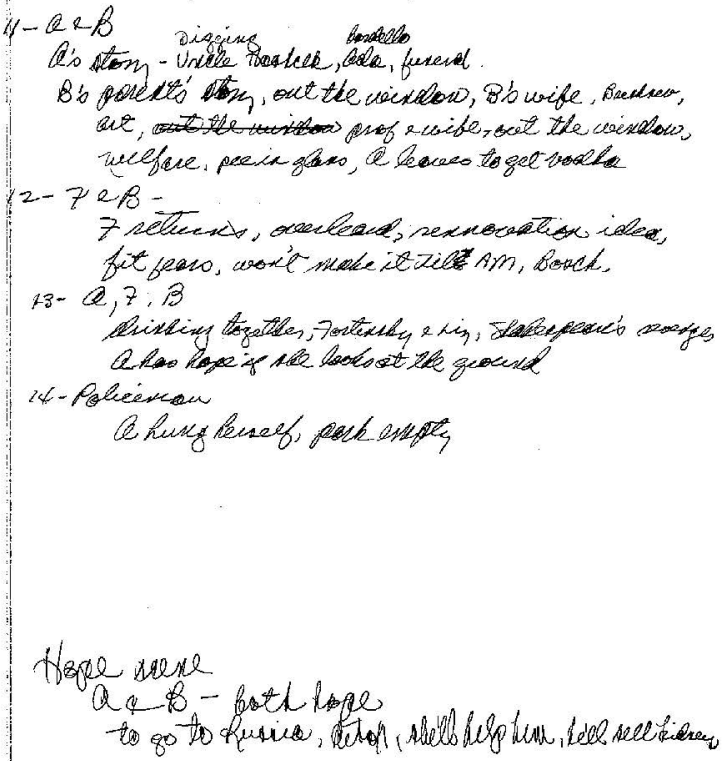




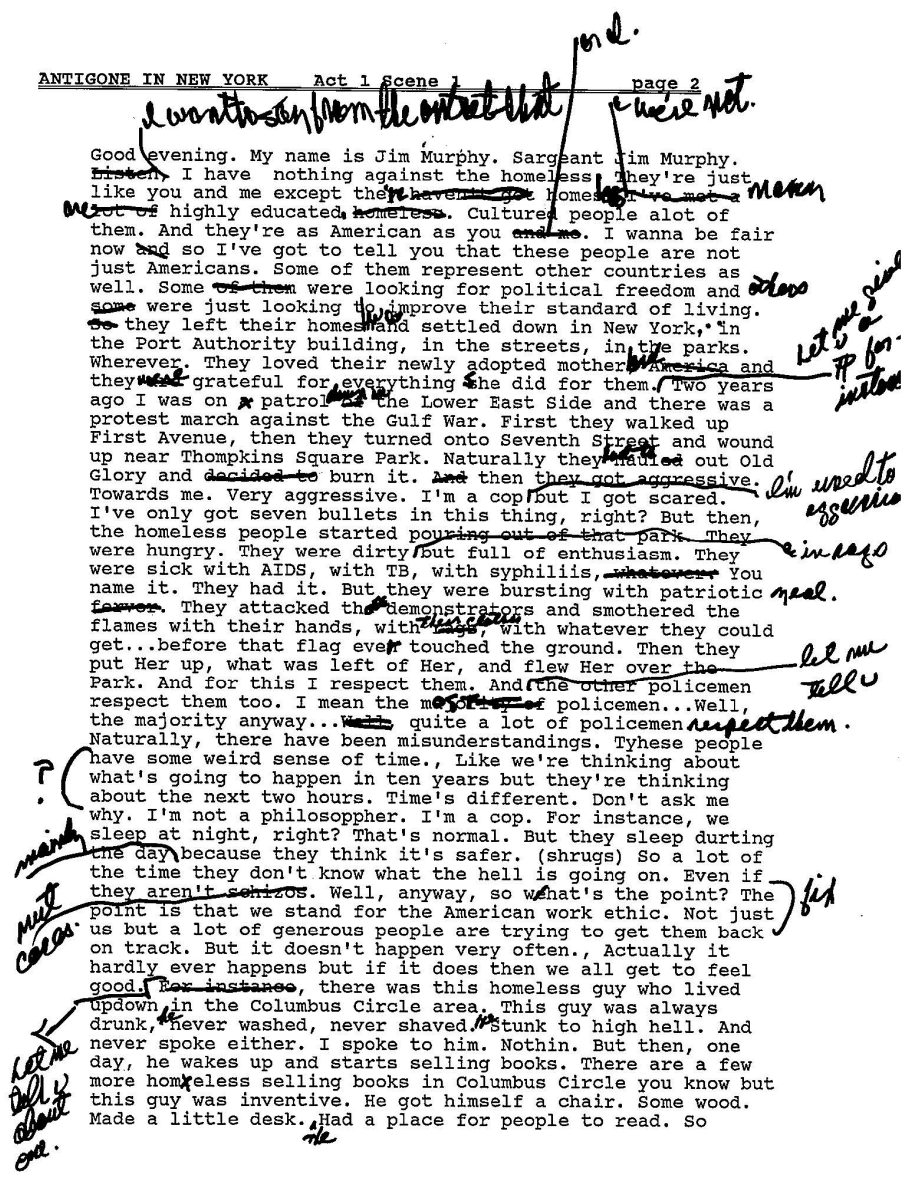

Ryc. 3-4 EN 1, akt I, scena 1. Dzięki uprzejmości Joan Torres 


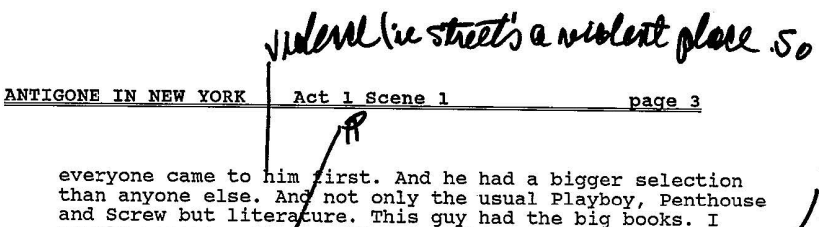

than anyone else. And not only the usual Playboy, Penthouse and Screw but literafure. This guy had the big books. I myself bought a stephen King from him that was that thick. And let me tell you, if some jealous bastard hadn't strangled him anf hrown his body in the Hudson ho' have an apartment by now/one of the things I try to do/is talk these people into moving to the shelters. There's a lot of shelters in this city. But they give me hard time about it. like I told one guy this morning, move to the shelter. And what does he say? He says he's afraid. Jesus! About what I asks him. Afterall the number of rapes, robberies and murders in those places ifn't much more than on the streets. And he'd be indoors. But he says why. (shrugs) Why. To be civilised I say. (S2axaifhe hays why. And I say lots of those places have TVs $\$$. 1 could participate in the culture a little gonna die and you know what he says? Why! the what does he this is, a coukse in existentialism? I don't know why. I'm a cop. Jesus $/ H$. Chript

Excuse me.

(he answers the call and talks Yeah. Murphy here. Yeah. Yeah. Okay.

Sorry. We've got a domestic on lith Street. I'll be back. 